\title{
Physical mapping of four porcine 20S proteasome core complex genes (PSMA1, PSMA2, PSMA3 and PSMA6)
}

\author{
X. Wu, ${ }^{a, b}$ S.H. Zhao, ${ }^{b}$ M. Yu, ${ }^{b}$ Z.M. Zhu, ${ }^{a}$ H. Wang, ${ }^{a, b}$ H.L. Wanga,b and K. Lia \\ a Department of Gene and Cell Engineering, Institute of Animal Science, Chinese Academy of Agricultural Sciences, Beijing; \\ ${ }^{\mathrm{b}}$ Laboratory of Molecular Biology and Animal Breeding, School of Animal Science and Technology, \\ Huazhong Agricultural University, Wuhan (P.R. China)
}

Manuscript received 12 July 2004; accepted in revised form for publication by H.P. Klinger 20 August 2004.

\section{Rationale and significance}

Proteasomes are protein complexes in eukaryotic cells that degrade proteins into peptides, some of which are involved in presentation by major histocompatibility complex class I molecules. The $20 \mathrm{~S}$ proteasome has a columnar shape with four rings which act as a catalytic core in protein degradation. The $20 \mathrm{~S}$ proteasome consists of 28 protein subunits that are encoded by 17 protein subunit genes. In this study, we successfully isolated four genes, PSMA1, PSMA2, PSMA3, and PSMA6. Furthermore, the four genes are assigned to porcine chromosomes.
This work was supported by the initial funding of CAAS, the Key Project of National Natural Science Foundation of China (30330440), the key Project of National Basic Research and Developmental Plan of China (G2000016103), National High Science and Technology Foundation of China (2004AA222170) and National Natural Science Foundation of China (30270952). The RH panel was kindly provided by Dr Martine Yerle of INRA, France.

Corresponding author: K. Li, Department of Gene and Cell Engineering Institute of Animal Science, Chinese Academy of Agricultural Sciences Beijing 100094 (P.R. China); telephone: +86-10-62833312

fax: +86-10-62899982; e-mail: lkxblghi@public.wh.hb.cn, likuihau@yahoo.com

\section{Materials and methods}

\section{Isolation and sequencing of four porcine gene fragments}

Human cDNA sequences of the four genes were obtained from NCBI (GenBank accession numbers are NM_002786, NM_002787, NM_002788, and NM_002791) and were compared with all sequences respectively in the EST-other databases by using the BLAST (www.ncbi.nlm.nih.gov/blast/) algorithm. Pig ESTs with at least more than $80 \%$ similarity with the corresponding human mRNA were chosen and aligned together using SaqMan. The primers were designed from the pig ESTs by using primer design software (Primer 1.0) (Table 1).

The PCR was conducted in a $20-\mu 1$ reaction volume consisting of $50 \mathrm{ng}$ of porcine genomic DNA, $1 \times$ PCR buffer, $0.3 \mu \mathrm{M}$ of each primer, $75 \mu \mathrm{M}$ of each dNTP, $1.5 \mathrm{mM} \mathrm{MgCl}_{2}$ and $2 \mathrm{U}$ Taq DNA polymerase (Promega, Madison WI, USA). The PCR parameters were $5 \mathrm{~min}$ at $94^{\circ} \mathrm{C}$ followed by $20 \mathrm{~s}$ or $30 \mathrm{~s}$ at $94{ }^{\circ} \mathrm{C}, 20 \mathrm{~s}$ or $30 \mathrm{~s}$ at the annealing temperature (Table 1 ) and $20 \mathrm{~s}$ or $30 \mathrm{~s}$ at $72{ }^{\circ} \mathrm{C}$ for 35 cycles and an extension of $8 \mathrm{~min}$ at $72^{\circ} \mathrm{C}$. The PCR products were purified with Wizard prep PCR purification system (Promega, Madison, WI, USA), cloned to Promega pGEM-T easy vector and sequenced by a commercial service. Comparisons of pig exon sequences of the four gene's PCR products with the corresponding human mRNA sequences in the GenBank were done using the BLAST2 software provided by the NCBI server (http://www.ncbi.nlm.nih.gov/blast/bl2seq/bl2.html) to confirm that the expected pig sequences were isolated.

\section{Radiation hybrid (RH) mapping}

The same primers were used in mapping (Table 1) and the mapping results are shown in Table 2. The 25-ng RH template was used in $10 \mu \mathrm{PCR}$ reactions $\left(94{ }^{\circ} \mathrm{C}\right.$ for $30 \mathrm{~s}, 58-60{ }^{\circ} \mathrm{C}$ for $30 \mathrm{~s}$, then $72{ }^{\circ} \mathrm{C}$ for $20 \mathrm{~s}$ for 31 cycles in a Mastercycler gradient with a final extension of $72{ }^{\circ} \mathrm{C}$ for $8 \mathrm{~min}$ ). The PCR products were size-separated on a $1.5 \%$ agarose gel and then stained with $0.5 \mu \mathrm{g} / \mathrm{ml}$ ethidium bromides. The PCR typing of each gene was done twice.

\section{Results and discussion}

The PCR results for the four genes were analyzed using the IMpRH mapping tool available through the IMpRH Web Server (http://imprh.toulouse.inra.fr/). In this study, we reported

\begin{tabular}{lll}
\hline KARGER & $\begin{array}{l}\text { Fax +4161306 12 34 } \\
\begin{array}{l}\text { E-mail karger@karger.ch } \\
\text { www.karger.com }\end{array}\end{array}$ & $\begin{array}{l}\text { 0 2005 S. Karger AG, Basel } \\
\text { 0301-0171/05/1084-0363 } \$ 22.00 / 0\end{array}$
\end{tabular}

Accessible online at: www. karger.com/cgr 
Table 1. Primer pairs used for porcine PSMA1, PSMA2, PSMA3 and PSMA6

\begin{tabular}{|c|c|c|c|c|c|c|}
\hline $\begin{array}{l}\text { Gene } \\
\text { symbols }\end{array}$ & $\begin{array}{l}\text { GenBank } \\
\text { Acc. No. } \\
\text { (porcine) }\end{array}$ & $\begin{array}{l}\text { Sequence } \\
\text { similarity }\end{array}$ & $\begin{array}{l}\text { Primer sequences } \\
\left(5^{\prime}-3^{\prime}\right)\end{array}$ & $\begin{array}{l}\text { Primer } \\
\text { binding } \\
\text { region }\end{array}$ & $\begin{array}{l}\text { Size } \\
\text { (bp) }\end{array}$ & $\begin{array}{l}\mathrm{Tm} \\
\text { value } \\
\left({ }^{\circ} \mathrm{C}\right)\end{array}$ \\
\hline PSMA1 & AY680661 & $94 \%$ & $\begin{array}{l}\text { PF-CTCTGCCTGTGTCTCGTCTT } \\
\text { PR-GTACGAGCTGATTGAGAACG }\end{array}$ & $\begin{array}{l}\text { exon } 6 \\
\text { exon } 8\end{array}$ & 1487 & 59 \\
\hline PSMA2 & AY680662 & $93 \%$ & $\begin{array}{l}\text { PF-GGAACTTGAAGATGCCATTC } \\
\text { PR-GGATTTTCAGTCACTTCGTT }\end{array}$ & $\begin{array}{l}\text { exon } 7 \\
\text { exon } 8\end{array}$ & 266 & 58 \\
\hline PSMA3 & AY680663 & $92 \%$ & $\begin{array}{l}\text { PF-CAAAAGATATAAGGGAAGAG } \\
\text { PR-TAGATGCTGAAGTAGGTGTT }\end{array}$ & $\begin{array}{l}\text { exon } 10 \\
\text { 3'UTR }\end{array}$ & 489 & 58 \\
\hline PSMA6 & AY680664 & $96 \%$ & $\begin{array}{l}\text { PF-GGTGGCCTTACATCAGTAGC } \\
\text { PR-GCTGTCATTCCTGTCATCAC }\end{array}$ & $\begin{array}{l}\text { exon } 2 \\
\text { exon } 3\end{array}$ & 634 & 60 \\
\hline
\end{tabular}

The pig sequences were compared to the corresponding human sequences.
Table 2. RH mapping of porcine PSMA1, PSMA2, PSMA3 and PSMA6

\begin{tabular}{llllllll}
\hline \multirow{2}{*}{$\begin{array}{l}\text { Gene } \\
\text { symbol }\end{array}$} & \multirow{2}{*}{$\begin{array}{l}\text { GenBank } \\
\text { Acc. No. } \\
\text { (human) }\end{array}$} & $\begin{array}{l}\text { Human } \\
\text { cytogenetic } \\
\text { location }^{\text {a }}\end{array}$ & & Porcine RH mapping result & & \\
\cline { 7 - 8 } & & & Retention (\%) & Lod score & Closed marker & Chr & Dist (cR) \\
\hline PSMA1 & NM_002786 & $11 \mathrm{p} 15.1$ & 26 & 5.66 & SW1026 & $2 \mathrm{p} 11$ & 68 \\
PSMA2 & NM_002787 & $7 \mathrm{p} 13$ & 34 & 12.77 & SWR414 & $18 \mathrm{q} 24$ & 33 \\
PSMA3 & NM_002788 & $14 \mathrm{q} 23$ & 24 & 10.78 & S0357 & $1 \mathrm{q} 21 \rightarrow \mathrm{q} 27$ & 38 \\
PSMA6 & NM_002791 & $14 \mathrm{q} 13$ & 18 & 10.4 & NFKB & $7 \mathrm{q}$ & 39
\end{tabular}

a The locations of genes of the human map were collected from http://www.ncbi.nlm.nih.gov/Locuslink/ locations of the four genes by choosing the closest markers with LOD scores higher than 5.0. Porcine gene PSMA1 was assigned to SSC2p11 and the linked marker was SW1026. PSMA2 was assigned to SSC18q24 with the marker SWR414. Both PSMA3 and PSMA6 were located on HSA14, but the porcine genes PSMA3 and PSMA6 were assigned to SSC1q21 $\rightarrow \mathrm{q} 27$ and SSC7q separately, with markers SWR414 and NFKB. The results were consistent with the known homology between HSA14 and SSC1 and SSC7 respectively (Table 2).

\section{References}

Coux O, Tanaka K, Goldberg AL: Structure and functions of the $20 \mathrm{~S}$ and $26 \mathrm{~S}$ proteasomes. A Rev Biochem 65:801-847 (1996).

Schweisguth F: Dominant-negative mutation in the b2 and b6 proteasome subunit genes affects alternative cell fate decisions in the Drosophila sense organ lineage. Proc Natl Acad Sci USA 96:11382-11386 (1999).

Ottosen S, Herrera FJ, Triezenberg SJ: Transcription. Proteasome parts at gene promoters. Science 296:479-481 (2002).

McCusker D, Jones T, Sheer D, Trowsdale J: Genetic relationships of the genes encoding the human proteasome beta subunits and the proteasome PA28 complex. Genomics 45:362-367 (1997).

Milan D, Hawken R, Cabau C, Leroux S, Genet C, Lahbib Y, Tosser G, Robic A, Hatey F, Alexander L, Beattie C, Schook L, Yerle M, Gellin J: IMpRH server: an RH mapping server available on the Web. Bioinformatics 16:558-559 (2000).

Yu M, Wang Y, te Pas MFW, Yerle M, Liu B, Fan B, Xiong T, Li K: Investigation of the porcine PA28 activator $\gamma$-subunit (PSME3) gene: isolation, polymorphism and its chromosomal localization. J Anim Bred Genet 121:142-148 (2004).

Wang Y, Yu M, Yerle M, Liu B, Zhao S, Xiong T, Fan B, Li K: Mapping of genes encoding four ATPase genes and three non-ATPase components of the pig $26 \mathrm{~S}$ proteasome. Anim Genet 34:393-395 (2003).

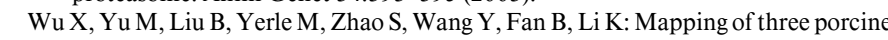
$20 \mathrm{~S}$ proteasome genes using the IMpRH panel. Cytogenet Genome Res 106:142E (2004). 